The authors wish to thank Miss Christine O'Hara for her assistance in the preparation of this manuscript.

F CASTILLO
J LUCAYA
N TOKASHIKI
J BRUNA
G PEGUERO
A GALLART
Departments of Neonatology and Radiology,
Hospital Materno-Infantile Valle Hebrón,
Universidad Autónoma de Barcelona,
Barcelona, Spain

1 Fraser RG, Pare JAP, Fraser RS, Genereux GP. Diagnosis of diseases of the chest. 3rd Ed. Philadelphia: WB Saunders, 1989: 81-102.

2 Kending EL. Disorders of the respiratory tract in children. 5th Ed. Philadelphia: WB Saunders, 1990: 253-4.

3 Stocker JT, Madewell JE, Drake RM. Congenita cystic adenomatoid malformation of the lung:
classification and morphologic spectrum. Hum Pathol 1977; 8: 155-71.

4 Fina A, Salcedo S, Tokashiki N, Martinez Ibañez $\mathrm{V}$, Peguero $\mathrm{G}$. Intubación bronquial selectiva adquirida en recien nacidos afectos de distres adquirida en recien nacidos afectos de distres
respiratorio. Medicina Intensiva 1987; 11: respirato

\section{Diagnosis of non-immune hydrops in the newborn}

EDITOR,-Stephenson et al provide a helpful 'personal practice' article in relation to nonimmune hydrops of the newborn and a near comprehensive list of reported associations. ${ }^{1}$ With such heterogeneity in the causes and associations of non-immune hydrops it is perhaps inevitable that the list is not absolutely complete and I write to highlight one potentially important omission, namely congenital myotonic dystrophy (CMD). Stratton and Patterson recently confirmed this diagnosis by DNA mutation analysis in a case of non-immune hydrops and provide a good literature review of hydropic infants born to mothers with myotonic dystrophy, a total of 16 cases including their own. ${ }^{2}$ Such numbers, although only a minority of those with CMD, suggest a clear cause and effect relationship rather than a chance association. The precise pathophysiology is undetermined but myotonic dystrophy is a multisystem disorder with cardiac muscle and conduction pathways significantly affected in a proportion of patients. There is good evidence that earlier onset, more severe forms of myotonic dystrophy will fair worse in this respect. The youngest case personally known to me who required a pacemaker did so at 16 years of age. It is reasonable to postulate that nonimmune hydrops in CMD may result from unusually severe cardiac muscle involvement with intrauterine heart failure - but this is speculation at present. As Stratton and Patterson point out, ${ }^{2}$ in unexplained nonimmune hydrops an examination of the mother and a detailed family history may provide the all important clues. The inheritance of myotonic dystrophy is autosomal dominant and the phenomenon of 'anticipation' is observed, that is, the age of onset of symptoms is earlier, and the severity of most features increased, with succeeding generations. It is virtually always the case that the affected parent of a baby with CMD is the mother and she can be expected to show at least some clinical signs of the disorder. However, the diagnosis must be considered first. Once CMD has occurred in one pregnancy it is highly likely that the next fetus to inherit the myotonic dystrophy gene will also manifest the congenital form. Of course, once a diagnosis of $\mathrm{CMD} /$ myotonic dystrophy has been made then genetic counselling and testing can be offered to other family members at risk.

PETER D TURNPENNY Clinical Genetics Service, Department of Child Health, Royal Devon and Exeter Hospital (Wonford) Exeter EX2 $5 D W$

1 Stephenson T, Zuccollo J, Mohajer M. Diagnosis and management of non-immune hydrops in 2 Stratton RF, Patterson RM. DNA confirmation of congenital myotonic dystrophy in nonimmune hydrops fetalis. Prenat Diagn 1993; 13: 1027-30.

\section{Patent ductus arteriosus in the newborn}

EDITOR,-In situations and places where injectable indomethacin is unavailable, oral indomethacin has been used for closure of the patent ductus arteriosus (PDA). It is, however, extremely difficult to fractionate accurately $25 \mathrm{mg}$ of the capsule (powder) into $0.2 \mathrm{mg}$ sachets or doses, especially when sensitive weighing scales may also not be available. We noted that oral indomethacin powder does not disperse easily in water or other liquid vehicles. We have hence used mefenamic acid, another non-steroidal antiinflammatory drug, as an alternative for treatment of symptomatic PDA. ${ }^{12}$ Mefenamic acid (Ponstan, Parke-Davis 50 $\mathrm{mg} / 5 \mathrm{ml}$ ) was administered orally in three doses of $2 \mathrm{mg} / \mathrm{kg} /$ dose at 12 hourly intervals in 25 neonates with symptomatic PDA. ${ }^{3}$ The mean gestation age of these neonates was 30 weeks, mean birth weight $1320 \mathrm{~g}$, and mean age of administration of mefenamic acid was 16 days. Twenty neonates had pretherapeutic two dimensional echocardiography and Doppler flow studies performed to confirm the diagnosis of PDA and to rule out a ductus dependent state. Twenty two patients $(88 \%)$ clinically responded to this therapeutic regimen within 48 hours of administration of the last dose of mefenamic acid. Of three non-responders one was subsequently diagnosed to have an endocardial cushion defect and the other two were then administered three doses oral indomethacin $(0.25 \mathrm{mg} / \mathrm{kg}$ dose $)$ with no therapeutic response.

Our earlier experience with the use of oral indomethacin in 32 preterms of mean gestational age 31 weeks indicated a PDA closure rate clinically of $75 \%$ in those treated with indomethacin.

Our initial experience with mefenamic acid treatment, although restricted to 25 cases, suggests that it is effective, safe, well tolerated, and certainly easier to administer than oral indomethacin. In situations where injectable indomethacin is not available, we suggest that mefenamic acid be used given its efficacy and ease of administration of accurate dosage. Further trials need to be conducted in larger number of cases to confirm our observations.

$$
\begin{array}{r}
\text { R H MERCHANT } \\
\text { V S SAKHALKAR } \\
\text { Division of Neonatology, } \\
\text { B f Wadia Hospital for Children, } \\
\text { Parel, Bombay } 400012, \\
\text { India }
\end{array}
$$

1 Shimada S, Kotaro O, Fujiwara T, Konishi M, Natamura $\mathrm{K}$. Hemodynamic changes in infants with RDS following surfactant therapy. Pediat Res 1986; 20: 371A

2 Shimada S, Raju T, Bhat R, et al. Early PDA ligation in surfactant treated animals with hyaline membrane disease does not improve pulmonary function. Pediatr Res 1987; 21: pulmo.

3 Sakhalkar VS, Merchant RH. Therapy of symptomatic patent ductus arteriosus in preterms using mefenamic acid and indomethacin Indian Pediatr 1992; 29: 313-8. 